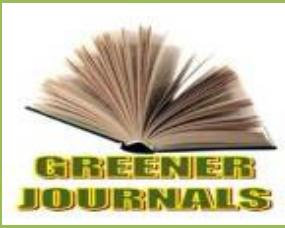

\title{
Determinant of Gross Margin in Vegetable Production: Case Study of Iwo Zone of Osun State
}

\section{Sodiq Ayodeji Ridwan and *Adeyemo Abolade Olufemi}

\author{
Department of Agricultural- Science, Afe Babalola University Ado-Ekiti, Nigeria
}

ARTICLE INFO

Article No.: 050115057

DOI: 10.15580/GJAS.2015.4.050115057

Submitted: 01/05/2015

Accepted: 05/05/2015

Published: 14/07/2015

${ }^{*}$ Corresponding Author

Adeyemo Abolade Olufemi

E-mail: boladeadeyemo@gmail. com

Phone: 08034129007

\section{Keywords:}

Gross margin; Agricultural

development programme;

vegetable
This study examined the determinant of gross margin in vegetable production, a case study of Iwo Zone of Osun state of Agricultural Development Programme (ASDP). Data were collected by administering 120 questionnaires to vegetable farmers selected through multistage sampling procedure. The data collected were subjected to descriptive and inferential statistics. The result of the findings revealed that majority $(60.0)$ of the vegetable farmers were between the ages of $46-$ 50 years. The mean age was 46 years. Majority $(84.17 \%)$ of the farmers were married and $73.3 \%$ of the vegetable farmers had no formal education which was a major problem that compounded their gross margin. Most of the farmers $(45.83 \%)$ procured their input from OSSADEP and less than half $(39.17 \%)$ of the farmers got their farming land on rent. The study further revealed that the labour cost, cost of fertilizer, cost of seed were the main determinants of the gross margin in vegetable production which were significant at $10 \%$ and $1 \%$ levels of significance respectively. In the light of all this, it was recommended that formal education should be provided to the farmers informally to serve as motivation to them, in adopting improved farming practices and the government should provide highly subsidized equipment to the farmers at low cost to reduce their labour cost. 


\section{INTRODUCTION}

Nigeria has a population of over 100 million people and about 93 million hectares of land, making it predominantly an agrarian country (NPC, 1992). Moreover, about $70 \%$ of its population engage in agriculture, yet the country is not self sufficient in food production (Obasi et al, 2000). It is however important that farmers continually seek increase in productivity and farm gross margin despite enormous challenges bedeviling their production. Government and Nongovernmental organizations remain strong hold in salvaging the Nigerian farmers' state, especially vegetable farmers, who offer vitamins and plant protein to households in the country. Consumption of fruit and leafy vegetables in many regions of the developing countries is however, a persistent phenomenon in the food consumption pattern survey (Agricultural and Consumer Protection). According to Tsoho et al (2002), majority of vegetable farmers are small holders of land acquired mainly through inheritance. Various constraints perceived by farmers include; non-availability of credit and low produce prices among others. This holds potential of low turnover on income and production in the coming season; this implies that when the quantity of planting materials increased the output of their vegetable would also increase (Udoh et al, 2007).

The productions of vegetables are affected by the in availability of the necessary resources at farmer's disposal, most especially land which are mostly acquired through inheritance by farmers (Salan et al, 2012). This has in turns been having negative effect on the income of the farmers.

Furthermore, most arable crop farmers are dominated by female farmers (Udoh et al, 2012) and this makes the production of vegetable to be small and non-attractive.

In Asian countries Indonesia in particular, as one of the biggest vegetable production country compare to other countries Asian countries vegetable production in Indonesian is of good quality and in high production (FAO, 2002).

Various constraint encountered by the farmers include low produce price, high cost of improved inputs, non availability of land, pest and diseases which possibly may impact negatively on the farmers input used in production.

This study intends to achieve the following specific objectives: -

1) To examine the socio-economic characteristics of the vegetable farmers

2) To determine the determinant of gross margin among the vegetable farmers in the study area.

\section{MATERIALS AND METHODS}

The study area is Iwo zone of Osun State Agricultural Development Programme (ADP). There are seven local government area in the zone namely; Iwo, Irewole, Ejigbo, Ayedire, Ayedaade, Isokan, Ola-Oluwa. The vegetable farmers are concentrated in the rural areas of the zone. Iwo zone has an area of $245 \mathrm{~km}^{2}$ and a population of 120,919 people (NPC, 2006). People of Iwo zone are primarily of Yoruba descent and the zone's primary economic activity is agriculture with the primary crops being cocoa, yam, corn, cassava and vegetable. The geographical and topographical characteristics of the zone favor vegetable production.

Sample and Data Collection: Multistage sampling technique was employed in the selection of representative sample for the study. The first stage involves the random selection of Iwo Zone from Three (3) Agricultural Zones in Osun State. The second stage involves the simple random selection of three (3) local governments namely: Iwo, Oladuwa, and iyedire local government areas. Six farming communities were randomly selected from each of the local government areas (Olubooku, Feesu, Idiobi, Asipa, Afiku, Telemu). Twenty Agricultural Development Programme (ADP) farmers were selected from each community, to make up one hundred and twenty (120) sampled farmers. Structured interview schedule was used to obtain information from farmers.

Analytical Technique: The data collected were analyzed using descriptive statistics (frequency distribution and percentages) for the socio economic characteristics of vegetable farmers. Also, multiple regression analysis was used to identify the determinant of gross margin among the vegetable farmers in the study area.

\section{RESULTS AND DISCUSSION}

One of the objectives of the study is to examine the socio economic characteristics of the vegetable farmers in the study area. The selected socio economic factors that were considered are Age, Marital Status, Farming experience, years of formal education, land acquisition. They are discussed below;

Table 1 shows that majority of the vegetable farmers are between the age of 46-55 years, with a mean age of 46 years. This means that majority of the farmers are middle aged. Most of the vegetable $(84.17 \%)$ farmers are married meaning that many of the farmers involve their spouses and children for labour in vegetable farming. Formal education among the vegetable farmers is low. Most of the farmers don't have formal education (73.3\%) while only few have (26.7\%) formal education. These results are in line with the findings of Busari and Omonone (2010) that there is low level of education among small scale farmers. Most of the vegetable farmers (45.83\%) procure their input from Osun State Agricultural Development Project. This 
shows that the farmers have access to quality inputs used in their production. Less than half $(39.17 \%)$ of the vegetable farmers obtain their land by rentage for their production. Rent as the most common means of getting land by the farmers which can likely be one of the determinants of their gross margin. Since their income would be shared between the vegetable farmers and owners of land.

Table 2 shows the result of the regression analysis. In table 2 , the coefficient of farm size $\left(X_{1}\right)$ is positive and statistically insignificant, showing that the farm size is positive related to gross margin from vegetable production. The coefficient of years of labour cost $\left(\mathrm{X}_{2}\right)$ is positive and it is statistically significant at $10 \%$ this implies that this variable is directly related to gross margin from vegetable production as more of labour is utilized, gross margin from vegetable production also increase. Similarly, the coefficient cost of equipment $\left(X_{3}\right)$ is negative and it is statistically insignificant. This means that cost of equipment is inversely related to gross margin from vegetable production. The coefficient of fertilizer cost $\left(\mathrm{X}_{4}\right)$ has positive sign and it is significant at $1 \%$ level. This means that the cost of fertilizer is a positive determinant of gross margin from vegetable production. The coefficient of cost of seed $\left(X_{5}\right)$ has a positive sign and it is significant at $1 \%$ level. This result indicated that cost of seed is a strong determinant of gross margin from vegetable production. The coefficient is also directly related to gross margin from vegetable production.

Table 1: The Socioeconomic Characteristics of the Respondents

\begin{tabular}{lll}
\hline Variable & Frequency & Percentage (\%) \\
\hline Age (Years) & 7 & 5.83 \\
$41-45$ & 72 & 60.00 \\
$46-50$ & 29 & 24.17 \\
$51-55$ & 12 & 10.00 \\
$56-60$ & 1 & \\
Marital Status & 101 & 0.83 \\
Single & 18 & 84.17 \\
Married & & 15 \\
Divorced & 88 & \\
Formal Education & 20 & 73.3 \\
0 & 12 & 16.7 \\
$1-6$ & & 10 \\
$7-12$ above & 39 & 32.5 \\
Input Source & 16 & 13.33 \\
Agbeloba & 55 & 45.83 \\
Alayo-cooperative & 10 & 8.33 \\
OSSADEP & & \\
Odo-Ori & 20 & 16.6 \\
Land-source & 12 & 10 \\
Family & 47 & 39.17 \\
Community & 41 & 34.17 \\
Rent & & \\
Purchase & &
\end{tabular}

Source: Field Survey 2012

Table 2: Result of Multiple Regression

\begin{tabular}{lllll}
\hline $\mathbf{Y}$ & Coefficient & Standard error & t-value & Probability \\
\hline $\mathrm{X}_{1}$ & 0.122 & 330.731 & 1.498 & 0.136 \\
$\mathrm{X}_{2}$ & $0.136^{\star * *}$ & 0.058 & 1.878 & 0.062 \\
$\mathrm{X}_{3}$ & -0.014 & 0.155 & -0.187 & 0.852 \\
$\mathrm{X}_{4}$ & $0.215^{\star}$ & 0.050 & 2.651 & 0.009 \\
$\mathrm{X}_{5}$ & $0.387^{\star}$ & 0.127 & 5.291 & 0.000 \\
\hline
\end{tabular}

Source: Field Survey 2012

${ }^{* * *}$ Indicate significant level at $10 \%$ and ${ }^{*}$ indicate significant level at $5 \%$

$$
\mathrm{R}^{2}=0.51
$$




\section{CONCLUSION}

This study analyzed the Determinant of Gross Margin from vegetable production among vegetable farmers in Iwo Zone of Osun State Agricultural Programme. The study reveals that most of the vegetable farmers are middle aged with low level of education which pounded more problems on their gross margin. Labour cost, fertilizer cost, and seed cost are significant determinant of gross margin from vegetable production in the study area.

\section{RECOMMENDATIONS}

1) Formal education should be provided informally to the vegetable farmers through the extension agents, this goes a long way in assisting the vegetable farmers to understand the use of modern technologies in vegetable production which will enhance their productivity and hence the gross margin realized from vegetable production.

2) Government should provide low cost or highly subsidized equipment to the vegetable farmers this will help to minimize the labour cost incurred by the vegetable farmers which will in turn help to improve their gross margin from vegetable production.

3) High quality seeds at lowest possible cost should be provided to the vegetable farmers so as to increase both the quality and the quantity of their output which will result to higher gross margins for the vegetable farmers.

\section{REFERENCES}

B. A. Tsoho and S. A. Salau (2012). Profitability and Constraints to Dry Season Vegetable Production under Fadama in Sudan Savannah Ecological Zone of Sokoto State, Nigeria. Journal of Development and Agricultural Economics Vol. 4(7), Pp.214-222.

Busari A. O. and Omonona, B. T. (2010). Resource use Efficiency among Rice Farmers in derived Savannah Zone Oyo State, Nigeria. Journal of Agricultural Science 1(1): 0-0(2010).

Edet J. Udoh and Sunday B. Akpan (2007). Measuring Technical Efficiency of Water Leaf (Talinum triangulae)

Oluwatoyin and Edet J. Udoh (2012). Resource use Efficiency and Productivity among farmers in Nigeria. Department of Agricultural Economics and Extension, University of Uyo, Uyo Nigeria.

P. C. Obasi, A. Henri-Ukoha, I. S. Ukewuile and N. M. Chidiebere (2000). Factors Affecting Agricultural Productivity among Crop Farmers in Imo State. American Journal of Experimental Agriculture. 3(2): 443-454, 2013. http://www.fao.org/3/ay5650e-pdf

\footnotetext{
Cite this Article: Sodiq AR and Adeyemo AO (2015).Determinant of Gross Margin in Vegetable Production: Case Study of Iwo Zone of Osun State. Greener Journal of Agricultural Sciences, 5(4): 118-121, http://doi.org/10.15580/GJAS.2015.4.050115057.
} 